\title{
PŮSOBNOST KOMISÍ PRO OBNOVU, PAMÁTKOVOU OCHRANU A VYUŽITÍ KAROLINA 1934-2017
}

\author{
JOSEF PETRÁŇ (†)
}

\section{ACTIVITIES OF COMMISSIONS FOR RECONSTRUCTION, HERITAGE CARE, AND UTILISATION OF THE CAROLINUM, 1934-2017}

Document-based study by a long-term member of the Historical Commission of the Charles University offers an overview of organisation of heritage care in the Carolinum and brings information about activities of the relevant commissions and their members. Their list is included at the end of the contribution.

Keywords: Carolinum - heritage case - Historical Commission

DOI: $10.14712 / 23365730.2018 .38$

Zákonem z 19. února 1920 (4 135 Sb.) byl areál Karolina po předchozích vleklých sporech přiřčen do vlastnictví Univerzity Karlovy v Praze. V předešlé době byla jeho vlastníkem Německá univerzita v Praze, která jej také převážně využívala, s výjimkou Velké auly, jež v určené dny v týdnu sloužila ke slavnostním účelům rovněž někdejší české Karlo-Ferdinandově univerzitě. Až po dalších čtrnácti letech sporů, dne 13. února 1934, potvrdil Univerzitě Karlově vlastnictví Karolina krajský soud civilní a mohl být proveden vklad vlastnického práva do pozemkových knih. ${ }^{1}$ Po tu dobu trvalo právo německé univerzity využívat při slavnostech velkou karolinskou aulu, než získá náhradní prostory. Až v roce 1938 pracoval architekt Josef Zasche na plánu výstavby ústřední budovy pro německou univerzitu na určeném staveništi na východním okraji Letné. Dokud Deutsche Universität in Prag nevystaví tuto budovu, mohla využívat pro slavnosti jiné prostory.

V tehdejších časech nacionálních sporů v prostředí univerzity se po staletí neudržovaný areál Karolina stal součástí politické propagandy, ač od rozdělení univerzity zůstával společným sídlem řízení a správy i prostorem $\mathrm{k}$ důstojným aktům. V českém nacionálním zájmu se Karolinum, „statek národní“, stalo vedle jiných momentů silnou složkou étosu generace rektora české Karlo-Ferdinandovy univerzity profesora Karla Domina a univerzitního archiváře profesora Václava Vojtíška. Byli to oni, kdo vyzdvihli „,národní“ podstatu dění, o němž se v budově od jejího založení rozhodovalo.

1 K tomu Václav VoJTíšek, Komise pro obnovu Karolina a její činnost, in: V. Vojtíšek (ed.), Karolinum. První zpráva o činnosti Komise pro obnovu Karolina v letech 1934-1936, Praha 1937, s. 7; Karel Litsch, Intabulace budovy Karolina podle nových knihovnich zákonů v 19. a 20. století, AUC-HUCP 26/2, 1986, s. 77-84. 
Univerzita Karlova musela s těmito komplikacemi počítat v době, kdy se s předstihem připravoval program obnovy Karolina, jež bylo po léta ve špatném stavebním stavu. Některé z návrhů na jeho přestavbu ze starší doby byly tak zásadní, že by středověkou stavbu v podstatě zrušily. Naštěstí se nerealizovaly. Už od roku 1906 ležel na stole plán na výstavbu nové ústřední univerzitní budovy pro tehdejší českou Karlo-Ferdinandovu univerzitu, a to naproti projektované stavbě právnické fakulty u Čechova mostu. ${ }^{2}$ Pokud by se měly uskutečnit projekty staveb ústředních budov Univerzity Karlovy v Praze u Čechova mostu a Deutsche Universität in Prag na kraji Letné, vyvstávala otázka, k jakým účelům by mělo sloužit obnovené Karolinum.

V ovzduší nacionálních sporů, v duchu hesla „Karolinum statek národní“, jež prožívala část veřejnosti před zaknihováním, ale i hned po zapsání Karolina Univerzitě Karlově v Praze do desek zemských, zvolil akademický senát Komisi pro obnovu Karolina. Ustavila se 2. května 1934 a měla dvě sekce: finanční a dále stavební a památkovou. ${ }^{3}$ Jejím předsedou se stal prorektor univerzity, profesor prŕírodovědecké fakulty Karel Domin, který již v předešlém akademickém roce jako rektor vyvíjel řadu patrioticko-nacionálních iniciativ. Finanční sekci (subkomisi) vedl architekt František Tesař, vrchní technický komisař zemského úřadu. Př̀edsedou stavební a památkové subkomise byl zvolen profesor dějin umění filozofické fakulty Vojtěch Birnbaum. Když krátce poté zemřel, převzal funkci profesor pomocných věd historických téže fakulty, univerzitní archivář Václav Vojtíšek. Ten byl vedle Domina, kterého po více než roce vystrrídal v čele Komise, jedním z nejhorlivějších nacionálně-patriotických představitelů programu přestavby Karolina. Přihlížel k zájmům univerzitního archivu, který řídil, a k jeho dalším působnostem, včetně představy ,univerzitního muzea“, což Komise přijala jako projekt ještě před zahájením obnovy přízemí historické budovy. 4

Když profesor Vojtíšek hovořil o „muzeu“, měl na mysli stálou expozici univerzitních dějin, umístěnou v přízemí Rotlevova paláce, již by připravil univerzitní archiv. $\mathrm{K}$ tomu směřoval výběr exponátů, jejichž fotografie Vojtíšek zčásti sám označil. Nepředpokládám tudíž, že by pomýšlel na samostatnou instituci muzea vedle archivu. Šlo spíše o trvalou historickou expozici, v níž by se rovněž uplatnily předměty, které - ač nearchivní povahy byly již dříve ukládány v archivním depozitáři. Sídlo archivu mělo být rovněž v přízemí Rotlevova paláce.

Členy památkové a stavební subkomise byli profesoři filozofické fakulty, a to profesor křest’anské archeologie Josef Cibulka, profesor pomocných věd historických Gustav Friedrich a historik umění Zdeněk Wirth. ${ }^{5}$ Dále tu byl profesor Vysokého učení technického

2 K tomu Alois KubíčeK (ed.), Karolinum a historické koleje University Kalovy v Praze, Praha 1961, s. 102; Josef Petráň (ed.), Památky Univerzity Karlovy, Praha 1999, s. 86 an. Závěry a podněty před vznikem komise srov. Jan Almer, Úprava Karolina, in: Za starou Prahu. Věstník pro ochranu památek 17, 1933, s. 22-24. Dále srov. Ladislav MACHOŇ, Karolinum, jeho stavební vývoj a námět pro restauraci, Zprávy veřejné služby technické 15/1, 1933, s. 208-213.

3 Václav Vostíšek (ed.), Karolinum. Prvni zpráva o činnosti Komise, s. 7. K tomu Archiv Univerzity Karlovy (dále AUK), fond Akademický senát Univerzity Karlovy (dále f. AS UK), sign. D 2/22, č. j. 3012/1933-34, 13. 4. 1934.

4 Srov. Václav VoJTíšEK (ed.), Za naši universitu, Praha 1936; тÝž, Karlova universita vždy jen naše, Brno 1946; Václav VoJTíšEK - Dobroslav LíBAL, Karolinum chlouba Univerzity Karlovy, Praha 1948.

5 AUK, f. AS UK, kart. 110, sign. D 2/22, složka Karolinum - restaurace 1934, č. j. 2260/1933-34, 18. 4. 1934. K tomu AUK, f. Filozofická fakulta Univerzity Karlovy, personálie pedagogického sboru, inv. č. 781, k. 68, 
v Praze Oldřich Stefan a zástupci Státního úřadu památkového, radové správně osvětové služby Karel Pekárek a Václav Wagner.

Subkomise ještě pod Birnbaumovým vedením stačila zahájit orientační stavebně-statický průzkum př́izemí, zčásti i sklepů Rotlevova paláce, nejstarší části Karolina. Průzkum provedli stavební odborníci a Birnbaum o něm vypracoval podrobnou zprávu. ${ }^{6}$ Patro, v němž byla Velká aula, zůstávalo zatím stranou, protože je spoluužívala Německá univerzita v Praze, jež tehdy nezískala náhradu. Po náhlém Birnbaumově úmrtí převzal dohled nad stavebním a statickým průzkumem profesor Oldřich Stefan, jenž připravil již podrobnější zprávu o průběhu prací a jejich výsledcích od sklonku ř́jina 1934 do poloviny března 1935. Na něho pak navázala zpráva F. X. Margolda, adjunkta Státního ústavu pro fotografování a měření památek (později Státní fotoměřický ústav). ${ }^{7}$ V letech 1934 až 1936, kdy stavebně statický průzkum plně řídila Komise pro obnovu Karolina, a to včetně stránky finančních nákladů, podařilo se jí na tehdejší dobu úspěšně provést stavební a statický průzkum přizemí a sklepů Rotlevova paláce, což byla nezbytná podmínka přestavbových prací. Na archeologický průzkum nebyl brán zřetel, což ostatně platí i pro pozdější období. Archeologické artefakty byly sbírány a ukládány bez náležitých nálezových zpráv, což napříště znemožnilo s těmito nálezy soustavně odborně pracovat. ${ }^{8}$

Po dva roky trvající stavební a statický průzkum v Karolinu (1934-1936), stejně jako první zabezpečovací práce, mohla Komise pro obnovu Karolina provádět díky finančním prostředkům vynaloženým Rektorátem Univerzity Karlovy v Praze. ${ }^{9}$ Vedle toho probíhala národní sbírka pro obnovu Karolina, vyhlášená a určená výhradně jen ,na opatření vnitřního zařizení v obnoveném Karolinu a na jeho umélecké ozdobeni a zdokonaleni". Obnova Karolina se stala prestižní záležitostí, čemuž nasvědčuje výnos sbírky, do níž přispěly podle svých možností veřejné osobnosti, instituce a firmy a dokonce i obsah kasiček z pouličních sbírek. Na široké propagaci se podílely články v novinách, umělci nabízeli nebo darovali k výzdobě obnoveného Karolina svá díla atd. Prozrazuje to mnohé, stejně jako výpravná publikace Karolinum statek národní, vydaná členy Komise pro obnovu Karolina. ${ }^{10}$ Nelze pominout též zahájení př́ípravy velkých Dějin Univerzity Karlovy, opět z iniciativy předsedy Komise pro obnovu Karolina profesora Václava Vojtíška. ${ }^{11}$

Vojtíšek Václav; inv. č. 103, k. 10, Birnbaum Vojtěch; inv. č. 128, k. 12, Cibulka Josef; inv. č. 222, k. 17, Friedrich Gustav.

6 Vojtěch BiRnBaum, Předběžná zpráva o stavebním probádání budovy a zpráva o loubí, in: Karolinum. První zpráva o činnosti Komise v letech 1934-1936, Praha 1937, s. 22-29.

7 Oldřich Stefan, Zpráva o výzkumu budovy v době od 22. ř́jna 1934 do 15. března 1934 (správně má být 1935), in: tamtéž, s. 30-38; František Xaver Margold, Přehled výzkumu v letech 1935-1936, tamtéž, s. 39-54; František TeSAř, Zpráva o stavebnich pracích, tamtéž, s. 55-62. Fotografická dokumentace uložena v AUK, f. Obnova Karolina, inventár̆ Jakub JAREš, Obnova Karolina - fotografie ze stavebně-historických průzkumů a z průběhu rekonstrukce, 1935-1953 (1956), manipulační seznam, Praha 2012; TÝž, Obnova Karolina. Fotodokumentace - dar stavitele Jana Lopaty, 1946-1975, dílčí inventár, Praha 2012.

8 Srov. Irena PAvLŮ, Středovéká keramika z Prahy-Karolina, Praehistorica 21, Varia archeologica VI, Praha 1994, s. 117-139; Zdeněk SMETÁnKA, Karolinum - svědectví dnešních sklepů, in: Josef Petráň (ed.), Památky Univerzity Karlovy, s. 13-20.

9 Viz obšírnou zprávu Václava VoJTíšKa, in: Karolinum. První zpráva o činnosti Komise, s. 17 ad.

10 Karel Domin - Václav VoJtišeK - Josef Hutter (edd.), Karolinum statek národní, Praha 1934, 2. vyd. 1935.

11 Milada SeKYrKová - Marek ĎurČAnskÝ, Dva dokumenty k počátkům př́pravy oslav univerzitního jubilea 1948. Generační pokus o syntézu dějin pražského vysokého učení, AUC-HUCP 56/1, 2016, 183-195. 
Když Deutsche Universität in Prag v roce 1936 konečně opustila karolinské historické prostory, bylo možné stavební a statický výzkum rozšířit i do poschodí s Velkou aulou. ${ }^{12}$ Náklady na průzkum tak neobyčejně narostly a rektorátní fondy a finanční dotace, jež měla Komise pro obnovu Karolina k dispozici, zdaleka nemohly pokrýt další práce, stejně jako následující obnovu, ${ }^{13}$ kterou byl nucen pokrýt stát. Komisi zůstal dohled nad stavebně-statickým průzkumem a vedle toho pak úkol stanovit využití Karolina a vyhlásit soutěž na projektanta obnovy. ${ }^{14}$ Otázka budoucího využití obnoveného areálu stála na prvním místě, nebot' vypracovaným programem se měl řídit architekt. Podle směrnice Komise mělo být zachováno Kaňkovo barokní průčelí do Železné ulice. Shoda byla i v tom, že by Velká aula už pro svou historickou tradici měla zůstat slavnostním shromaždištěm při promocích a univerzitních festivitách. K těmto účelům měla být zvětšena. Gotické články stavby, nalezené při stavebním průzkumu, měly zůstat zachovány a při obnově využity.

Důležitým rozhodnutím Komise bylo společné přesvědčení, že je třeba provést přístavbu k někdejšímu historickému rotlevskému jádru paláce, a to na místě sousedních budov, jež univerzita vlastnila. Což svědčí o tom, že se v budoucnu počítalo s návratem Rektorátu Univerzity Karlovy a s dalšími jejími součástmi do rozšířeného areálu obnovených karolinských staveb.

Převzetí finanční stránky obnovy Karolina zemským úřadem a ministerstvem veřejných prací odebralo Komisi nezvládnutelné břemeno. ${ }^{15}$ Nadále měla na starosti dokončení stavebního průzkumu a přípravu rekonstrukce, s čímž souvisel i výběr projektanta. Komise pro obnovu Karolina (název potvrzen rektorátem 6. listopadu 1936) se podle slov jejího tehdejšího vedoucího profesora Václava Vojtíška stala „odbornou pomocnicí akademického senátu i rektorátu university, s plným jejich porozuméním ve svých snahách a pracích". ${ }^{16}$ Její finanční subkomise zanikla.

V době dokončování stavebního průzkumu středověkého Rotlevova paláce a příprav k vyhlášení soutěže na výběr architekta postihla republiku německá nacistická okupace, po níž následovalo násilné převzetí Karolina německou univerzitou, která ted' přijala název Deutsche Karlsuniversität in Prag v rámci systému univerzit říšskoněmeckých. České vysoké školy byly 17. listopadu 1939 uzavřeny.

Urychlené přípravy obnovy Karolina z předešlých let ustaly. Němci převzali Komisí připravenou dokumentaci, ale na rekonstrukci nebyla za války vhodná doba ani prostředky. Deutsche Karlsuniversität in Prag svěřila projekt rekonstrukce Karolina německému pražskému architektu Josefu Zaschemu, který měl předtím projektovat ústřední budovu německé univerzity na okraji Letné. ${ }^{17}$

Deutsche Karlsuniversität in Prag neměla dost prostředků na obnovu Karolina, což zejména Velkou aulu uchránilo před znetvořením nacistickými symboly, navrženými architektem. Byly provedeny jen některé stavebně zajišt’ovací práce, z nich především betonový strop Velké auly.

\footnotetext{
A. KuBíčEK (ed.), Karolinum a historické koleje University Karlovy v Praze, s. 102.

Vynaložené částky za uplynulé období uvádí V. VoJTíšEK, Karolinum. První zpráva o činnosti Komise, s. 17.

K tomu A. KubíčEK (ed.), Karolinum a historické koleje University Karlovy, s. 102.

Výnos ministerstva veřejných prací č. j. 2a-1217 z r. 1936, č. j. 20693 z 15. 5. 1936.

V. VojtíšeK (ed.), První zpráva o činnosti Komise pro obnovu Karolina, s. 18.

17 A. KubíčEK (ed.), Karolinum a historické koleje University Karlovy v Praze, s. 103. O stavu prací na obnově Karolina před odevzdáním německé univerzitě informovali předseda Komise V. VoJTíšEK a F. X. MARGOLD, O výzkumu Karolina a o jeho výsledcích v posledních letech, in: Zprávy památkové péče 3, 1939, s. 24-30.
} 
V prvním poválečném roce zprvu vyvstala řada problémů, mezi jiným nedostatek stavebního materiálu, aby práce mohly podle plánu pokračovat a být dokončeny do chystaných oslav šestistého výročí založení Univerzity Karlovy v dubnu 1948.18 Profesor ČVUT Jaroslav Fragner, kterému byla přestavba svěřena v roce 1946, se proto v první etapě přestavby soustředil na rekonstrukci obřadní Velké auly a př́istupových prostor, aby se tu v roce 1948 mohly oslavy konat. Řídil se staršími pokyny Komise pro obnovu Karolina ze třicátých let a zachoval historické části, mezi nimi nově objevený gotický portál do Velké auly, kterou prostorově rozšíríl. Sama Komise po válce již neobnovila svou činnost a Fragner spoléhal na její někdejší závěry a doporučení, stejně jako na porady s jednotlivci.

Druhá etapa rekonstrukce historického areálu probíhala v prrízemí někdejšího Rotlevova paláce a přilehlého kř́́dla, dosavadními úpravami dosti poškozeného, a to až v letech po komunistickém převratu roku 1948. Slavnostně byla završena při příležitosti oslav 550. výročí Kutnohorského dekretu v roce $1959 .{ }^{19}$ Upraven byl tehdy vnitřní čestný dvůr a v něm umístěna socha $M$. J. Husa, dílo Karla Lidického. Pro nedostatek času a financí již Fragner nestačil dokončit projektované vybavení tzv. Vlasteneckého sálu v prvním patře traktu. $\mathrm{V}$ další etapě bylo přikročeno $\mathrm{k}$ utváření prostor pro budoucí sídlo rektorátu (včetně univerzitního archivu) v sousedních objektech. Poté tempo úprav širšího areálu, zejména v přilehlém traktu s průčelím do Celetné ulice, vázlo. Jejich restaurování se již do konce totalitního systému v roce 1989 nestihlo. Práce na variantních studiích celého areálu probíhaly pod vedením profesora Fragnera a jejich výsledný schválený projekt celého „uzavřeného univerzitního areálu na středověké urbanistické substrukci“ je z roku 1954.20 Fragner podle možností usiloval o to, aby „rekonstrukce osvobodila areál od utilitárních př́staveb, ozdravila a provzdušnila vnitřní prostředí, obnovila funkci prostoru mázhauzů zapojením do komunikačniho systému jak uvnitř uzavřeného areálu, tak umožnila obnovu historických pěšich komunikací napřič blokem mezi Celetnou a Ovocným trhem v čp. 563 a Malou Kamzíkovou v čp. 559“.21

Po vykročení univerzity do svobodného života při tzv. sametové revoluci roku 1989 ustavilo kolegium rektora zprvu Komisi pro další jednání o pracech v karolinském areálu, v níž byli čtyři pracovníci rektorátu a Miroslav Kunštát z Ústavu dějin a archivu Univerzity Karlovy. Počátkem akademického roku 1992/1993 se kolegium rektora rozhodlo nahradit ji širším poradním orgánem, Komisí pro památkovou ochranu a využití Karolina, která roku 1999 změnila název na Historickou komisi UK. Zpočátku měla Komise dvanáct členů, které na návrh akademického senátu jmenoval rektor. ${ }^{22}$ Jejími členy bylo sedm pracovníků rektorátu, z nich dva prorektoři, Jaroslav Mihule a Josef Petráň (ustaven předsedou Komise), dále též univerzitní kanclér Jan Kofroň a univerzitní kvestor Jan Winkler, vedoucí organizačního oddělení Václava Kupová a ředitel správy budov a zařízení Josef Rendl. Z přizvaných odborníků se stal oporou Komise Marian Bělohradský, žák a posléze asistent profesora Jaroslava Fragnera, který po Fragnerově smrti v roce 1967 pokračoval v realizaci

18 O problémech, jež zbrzdily postup prací a převzetí projektu Jaroslavem Fragnerem, viz Oldřich STARÝ, Obnova Karolina. Projekt: Jaroslav Fragner, Architektura ČSR 18/3, 1959, s. 77-92.

19 Tamtéž, s. 89

20 Nadále se opírám o složku Historická komise 1992-2017, uloženou na organizačním oddělení RUK, dále pak o prameny v mém vlastním držení.

21 RUK, organizační oddělení, Historická komise 1992-2017, př́iloha k zápisu Komise pro památkovou ochranu a využití Karolina z 8. 10. 1992, zpráva docenta Mariana Bělohradského.

22 RUK, organizační oddělení, Historická komise 1992-2017. 
plánu rekonstrukce Karolina. Díky bohaté dokumentaci, již shromáždil z Fragnerova ateliéru a z Archivu Univerzity Karlovy, mohl propojit starší plány rekonstrukce s novými projekty a posoudit jejich hodnotu i platnost. Zároveň též mohl upozornit na to, co se v prvních poválečných etapách nedotáhlo či neosvědčilo. $Z$ toho pak vycházela ve své práci Komise pro památkovou ochranu a využití Karolina jako ,poradní orgán rektora v otázkách univerzitnich tradic a památkové péče “. Komisi nadále jmenuje rektor po své inauguraci.

Z dalších odborníků jmenovaných členy Komise v roce 1992 byli dva docenti Filozofické fakulty Univerzity Karlovy, a to archeolog Zdeněk Smetánka z Ústavu pro pravěk a ranou dobu dějinnou a Jiří Kropáček z Ústavu pro dějiny umění. Z Ústavu dějin Univerzity Karlovy a archivu Univerzity Karlovy tu byli vedoucí archivu Miroslav Truc a zpočátku rovněž vědecký pracovník Miroslav Kunštát. ${ }^{23}$

$\mathrm{Z}$ důležitých úkolů Komise, jež daly podnět k jejímu ustavení, byly dva nejnaléhavější. Měla projednat a dát doporučení, jak využít obnovené gotické přízemí někdejšího Rotlevova paláce. Podle původních plánů ze třicátých let tu měl být umístěn univerzitní archiv a k němu připojené univerzitní „muzeum“. Mezitím byl pro Ústav pro dějiny UK, zřízený v roce 1960 z iniciativy profesora Václava Vojtiška, rekonstruován sousední nádvorní trakt karolinského areálu. Př́zemní křížová chodba Rotlevova paláce byla pronajímána ke komerčnímu využití jako prostor pro pořádání výstav. Komise o jejím budoucím využití jednala 10. prosince $1992 \mathrm{v}$ souvislosti s kategorizací jednotlivých prostor historické budovy a přilehlého areálu. ${ }^{24}$ Od představy umístit v prrízemní Krrížové chodbě univerzitní muzeum se upustilo. Nadále měla být výstavním prostorem především pro univerzitní expozice, zároveň však s možností využívat ji komerčně k př́ležitostným výstavám, pokud jejich obsah bude v souladu s duchem národní kulturní památky a s univerzitními tradicemi. $\mathrm{V}$ prostoru vedle kř́žové chodby měl vzniknout a být vybaven mobiliářem tzv. Císařský sál, pojmenovaný podle obrazů panovníků zavěšených v čele: Marie Terezie, Josefa II. a Leopolda II.

Po dobu rekonstrukce byla vzácnější díla karolinské obrazové galerie podle dohody vystavena v Muzeu hl. města Prahy, které vydalo i katalog. Po jejich navrácení Komise navrhovala rozmístění do jednotlivých prostor Karolina, pokud už jejich funkční využití nebylo dáno minulým stavem. ${ }^{25}$ Zároveň Komise doporučila kategorizaci i dalších slavnostních prostor Karolina. Tak byla Velká aula určena „výlučně pro slavnostní shromáždění, a to i př̀ vědeckých sympoziich apod., nikoliv pro jednáni s přednáškovou či diskusní náplni [...]. Pokud jde o koncerty, připouštěji se toliko koncerty pořádané univerzitou a jejími fakultami, jedinou výjimkou je tradiční zahajovací koncert Pražského jara." Podobně bylo rozvrženo využití dalších karolinských prostor, dodržované v podstatě podnes.

Se slavnostním otevřením „muzea“, stejně jako s nezbytnými opravami a dalšími rekonstrukčními úpravami prostor obnovených před lety Fragnerem, se počítalo k př́ležitosti oslav 650. výročí založení univerzity v roce $1998 .^{26}$

23 Tamtéž.

24 Tamtéž, zápis o jednání Komise pro památkovou ochranu a využití Karolina 10. 12. 1992.

25 Srov. vytištěný katalog výstavy Josef PetráŇ - Ivo KoŘÁn (edd.), Umělecká díla Karolina, Praha 1996.

26 K tomu Nora DolansKá, Nový kabát Karolina (rozhovor s doc. ing. arch. M. Bělohradským), Forum 1/3, 1995, s. 1-2, Forum on-line 3/95 (5. 5. 1995) dostupné na: <http://forum.cuni.cz/forum3-95/adhoc.ISO2.html> (ověřeno 13. 4. 2018). 
Dlouho proponované „muzeum“ se stalo předmětem dalších jednání Komise, která se nakonec shodla na tom, že není vhodné budovat je jako novou samostatnou instituci. Záměr vlastně od počátku směřoval k vymezení prostor pro stálou expozici k dějinám Univerzity Karlovy. ${ }^{27}$ Úkol byl svěřen Ústavu dějin Univerzity Karlovy a archivu Univerzity Karlovy, stejně jako prŕíprava dočasných výstav v křřžové chodbě, zvlášt' při různých univerzitních výročích. Stálá expozice s původním názvem 650 let cesty za poznáním a vzdělaností byla skutečně otevřena v době oslav roku 1998, a to v románských sklepních prostorách historické budovy, jež byly k tomuto účelu restaurovány a vybaveny mobiliářem, stejně jako př́istupové cesty do nich a přilehlé místnosti Klubu rektora. ${ }^{28}$ Nově a v rozšířeném pojetí byla tato expozice instalována roku 2014 u př́ležitosti slavností k výročí 17. listopadu. Suplováním muzejní instituce podstatně vzrostly nároky na Ústav dějin Univerzity Karlovy a archiv Univerzity Karlovy, jehož ředitel je členem Komise pro obnovu a využití Karolina (Historické komise Univerzity Karlovy). Od roku 2005 je jím profesor Petr Svobodný. $\mathrm{S}$ př́pravou stálé expozice souvisela i systematická evidence a zhodnocení památek univerzity. Po čtyřsvazkových Dějinách Univerzity Karlovy tak v roce 1999 vyšla výpravná kniha Památky Univerzity Karlovy. ${ }^{29}$

Druhým z naléhavých úkolů Komise pro památkovou ochranu a využití Karolina, vytčených hned v roce 1992, se stala nezbytná restaurace a doplnění obnovy areálu po čtyřech desítiletích od Fragnerovy přestavby. Blížící se jubilejní oslavy 650. výročí založení Univerzity Karlovy k tomu daly impuls. Potřebné úpravy se týkaly celého areálu mezi Ovocným trhem, Železnou, Kamzíkovou a Celetnou ulicí. Komise se nejprve vyjadřovala k výběru projektanta. Koncem dubna 1995 jím byl stanoven na základě vypsané soutěže pražský Projektový ateliér pro architektonické a pozemní stavby, přičemž vedoucím projektu se stal Tomáš Šantavý. ${ }^{30}$ Měl možnost využít starší projektové dokumentace docenta Bělohradského, připravené pro Státní ústav pro rekonstrukci památkových měst a objektů (SURPMO) v roce 1977, týkající se objektů v Celetné ulici.

Rok 1996 se stal nejvytíženějším v celém trvání Komise. Scházela se každý měsíc, někdy co týden, s architektem Šantavým a jeho asistenty, aby projednávali návrhy úprav, jež probíhaly rychlým tempem, aby se stihl konečný termín. Historická část Karolina byla kvůli probíhajícím pracím v roce 1996 pro veřejnost uzavřena. Počítalo se s jejím otevřením počátkem akademického roku 1997/1998, mnozí však právem pochybovali o možnosti termín dodržet. Vedle oprav opotřebovaných částí mobiliáře nebo jeho nahrazení novým bylo třeba počítat s výměnou technického vybavení, jako bylo elektrické vedení, zvuková technika, klimatizace atd., či např́íklad s vyř̌šením absence výtahu v historické budově a v rektorátním křídle na ni napojeném. Nehledě na nedokončenou úpravu Vlasteneckého sálu (stěny přikryty látkovými tapetami, umístěny bronzové odlitky bust, zavěšeny nové lustry, zrekonstruována podlaha) a celého bloku areálu obráceného do Celetné ulice. O každé části obnovy a úprav se vedly na zasedáních Komise rozpravy s architektem a jeho asistenty. Shoda panovala v tom, že je třeba provést rekonstrukci s velkou rozvahou a s co nejmenšími zásahy do historických objektů. Výtah byl nakonec projektován do rektorátního kř́íla

27 RUK, organizační oddělení, fasc. Historická komise 1992-2017.

28 Při této př́ležitosti byla vydána tiskem brožura (průvodce) 650 let cesty za poznáním a vzdělaností. Universitas Carolina. Výstava o vývoji Univerzity Karlovy, Praha 1998.

29 Josef Petráň (ed.), Památky Univerzity Karlovy, Praha 1999.

30 Doklady viz RUK, org. odd., fascikl Historická komise 1992-2017; Josef Petráň, Karolinum, Praha 2010. 
s tím, že odtud je po pavlači prrístup do Vlasteneckého sálu a okolí Velké auly. Dochované zápisy ze zasedání Komise pro památkovou ochranu a využití Karolina umožňují sledovat postup prací.

Náročné úkoly projektanta, navazující na Fragnerovu etapu, nemohly být ani při vskutku rychlém tempu prací završeny do výročí založení Univerzity Karlovy v roce 1998. Trvalo ještě nějaký čas, než skončila rekonstrukce tzv. Opitzova domu v bloku do Celetné ulice. Univerzita tu počítala s umístěním zařízení hotelového typu, v němž by mohli být ubytováni hosté po dobu návštěvy univerzity. Mělo být včleněno do tzv. Kongresového centra univerzity, které by využívalo Zelené a Modré posluchárny. V přízemí budovy mělo mít prodejnu univerzitní Nakladatelství Karolinum. Nevyužité poměrně rozsáhlé sklepní prostory měly být změněny v klubové místnosti, během dne otevřené studentům. Rekonstrukční a stavební práce v této etapě končily v letech 1999 až 2000.

Vedle uvedených problémů projednávala a schvalovala Komise náměty výstav v křížové chodbě historické budovy a projednávala i rektorova zadání, která se netýkala samotného Karolina. Tak tomu bylo zejména po změně názvu na Historickou komisi UK v roce 1999. $Z$ větších projektů se v letech 2004 až 2006 vyjadřovala $k$ postupu prací při zařizování promoční síně (auly), určené pro bakalářské promoce v budově Matematicko-fyzikální fakulty Univerzity Karlovy na Malostranském náměstí 25 v Praze 1 (v někdejším historickém refektáŕi jezuitského profesního domu), i k množství dalších předloh. Tak je tomu za předsednictví prorektora Jana Royta podnes. Za čtvrt století trvání Komise se v ní vystř́ídali vedle prorektorů Univerzity Karlovy a pracovníků rektorátu a Ústavu dějin Univerzity Karlovy a archivu Univerzity Karlovy odborníci z oborů architektury, dějin umění, archeologie a muzejnictví, a to z r̆ad univerzitní akademické obce i externistů.

\section{Členové Komise pro ochranu a památkové využití Karolina, později Historické komise Univerzity Karlovy, v letech 1992-2017}

jméno, doba členství v Komisi

pưsobiště (uvádí se zaměstnání a funkce v době jmenování členem Komise)

doc. ing. arch. Marian Bělohradský, 1992 - 16. 3. 1996

Státní ústav pro rekonstrukci památkových měst a objektů (SURPMO)

ing. Karel Höfer, 2006-2010

ředitel správy budov a zařízení UK

prof. PhDr. Mojmír Horyna, 2006-2010, předseda

prorektor UK, Ústav pro dějiny umění Filozofické fakulty UK

prof. PhDr. Ivan Jakubec, 2010-2014, predseda

zástupce ředitele Ústavu hospodářských a sociálních dějin Filozofické fakulty UK 
prof. PhDr. Jan Klápště, 2006-2010

ředitel Ústavu pro pravěk a ranou dobu dějinnou Filozofické fakulty UK

PhDr. Helena Koenigsmarková, 2010 - dosud

ředitelka Uměleckoprůmyslového muzea v Praze

ing. Jan Kofroň, 1992-2006

pracovník Rektorátu UK, rektorátní kancléř

ing. Petr Kostelecký, 1996-2005

pracovník Rektorátu UK, vedoucí odboru výstavby

doc. PhDr. Jiří Kropáček, 1992-2009

Ústav pro dějiny umění Filozofické fakulty UK

ing. Josef Kubíček, 2000-2010

kvestor UK

JUDr. Jan Kuklík, 1994-1996

Ústav dějin práva Právnické fakulty UK

PhDr. Miroslav Kunštát, 1992

vědecký pracovník Ústavu dějin UK a archivu UK

Václava Kupová, 1992-2014

pracovnice Rektorátu UK, vedoucí organizačního oddělení

prof. PhDr. Jaroslav Mihule, 1992-1994

prorektor UK

prof. PhDr. Josef Petráň, 1992-2017, předseda 1992-2005

prorektor UK, ředitel Ústavu dějin UK a archivu UK

Karel Př́lepek, 1993-2000

pracovník Rektorátu UK, oddělení realizace staveb

ing. Josef Rendl, 1992-1993

pracovník Rektorátu UK, ředitel správy budov a zařízení

prof. PhDr. Jan Royt, 2005 - dosud, předseda

prorektor UK, ředitel Ústavu pro dějiny umění Filozofické fakulty UK

ing. Lev Serbenský, 2000-2002

pracovník Rektorátu UK, ředitel správy budov a zařízení 
doc. PhDr. Zdeněk Smetánka, 1994-2010

Ústav pro pravěk a ranou dobu dějinnou Filozofické fakulty UK

PhDr. Lubomír Sršeň, 1996 - dosud

ředitel historického oddělení Historického muzea, Národní muzeum v Praze

prof. PhDr. Petr Svobodný, 2005 - dosud

ředitel Ústavu dějin UK a archivu UK

prof. ing. arch. Vladimír Šlapeta, 1996-2010

děkan Fakulty architektury ČVUT

doc. akad. maliřr Ivan Špirk, 2006 - dosud

Katedra výtvarné výchovy Pedagogické fakulty UK

prof. Stanislav Štech, 2003-2006

Pedagogická fakulta UK

PhDr. Miroslav Truc, 1992-1996

vedoucí archivu, Ústav dějin UK a archiv UK

prof. PhDr. Vít Vlnas, 2010 - dosud

ředitel Sbírky starého umění Národní galerie v Praze

prof. MUDr. Petr Widimský, 2000-2005

prorektor UK

ing. Pavel Wild, 1994-1996

pracovník Rektorátu UK, vedoucí odboru pro rozvoj

prof. ing. Ivan Wilhelm, 1994-2000

předseda Akademického senátu UK

prof. PhDr. Petr Wittlich, 1996 - dosud

Ústav pro dějiny umění Filozofické fakulty UK 


\title{
Der Wirkungsbereich der Kommissionen für Erneuerung, Denkmalschutz und Nutzung des Karolinums 1934-2017
}

\author{
ZUSAMMENFASSUNG
}

Die Materialstudie des langjährigen Mitglieds und Vorsitzenden der Historischen Kommission der Karlsuniversität bietet einen Überblick über die Organisation der Denkmalspflege im Karolinum, über die Tätigkeit entsprechender Kommissionen und ihrer Mitglieder. Ihr Verzeichnis befindet sich am Ende der Studie.

Der Überblick beginnt mit dem Jahr, in welchem das Gelände des Karolinums der tschechischen Karlsuniversität übergeben wurde und die Bemühungen um seine Rekonstruktion einsetzen, denn der Erhaltungszustand des Geländes war vernachlässigt und es bestand die Notwendigkeit, Grundsätze für seine bauliche Instandsetzung aufzustellen. Seinen Überblick lässt der Verfasser von der Peripetie des Zweiten Weltkriegs über die Zeit der kommunistischen Herrschaft bis in die Gegenwart gleiten. Er macht mit den verschiedenen Renovierungsphasen des Karolinums und den sich wandelnden Vorstellungen über seine Nutzung, die Einrichtung eines Museums udgl., bekannt.

Deutsche Übersetzung Wolf B. Oerter

Josef Petrán̆

Ústav dějin a archiv UK, Praha 